\title{
New records of lichens from the Zeysky Nature Reserve (Amur Region, Russia)
}

\author{
Ekaterina S. Kuznetsova ${ }^{1,2}$ \& Sergey V. Dudov ${ }^{3,4}$ \\ ${ }^{1}$ Department of Botany, St. Petersburg State University (SPbSU), Universitetskaya emb. 7-9, 199034 \\ St. Petersburg, Russia. E-mail: igel_kuzn@mail.ru \\ ${ }^{2}$ Laboratory of Lichenology and Bryology, Komarov Botanical Institute RAS, Professor Popov St. 2, 197376 \\ St. Petersburg, Russia \\ ${ }^{3}$ Department of Geobotany, Lomonosov Moscow State University, Leninskiye Gory, 119234 Moscow, Russia \\ E-mail: serg.dudov@gmail \\ ${ }^{4}$ Zeysky State Nature Reserve, Stroitelnaya St. 71, 676246 Amur Region, Zeya, Russia
}

\begin{abstract}
The lichen biota of the Zeysky Nature Reserve (southern Russian Far East) was studied in the course of geobotanical expedition. In total 36 species of lichens and one lichenicolous fungus are reported for the first time for the reserve. Among them 19 are new to the Amur Region. Parmelia asiatica is reported for the first time for the southern Russian Far East, Cladonia norvegica - for the Asian part of Russia, Tuckermannopsis gilva - for Russia, Melanohalea laciniatula - for Asia. Four species are included in the Red Data Book of Russian Federation.
\end{abstract}

Keywords: Russian Far East; Cladonia norvegica; Melanohalea laciniatula; Parmelia asiatica; Tuckermannopsis gilva

\section{INTRODUCTION}

There are a great number of publications devoted to lichens and allied fungi of the southern Russian Far East (incl. Amur Region, Jewish Autonomous Region, Primorye Territory, Sakhalin Region and Khabarovsk Territory in part). All available data were consolidated by Svetlana I. Tchabanenko in the lichen checklist of the southern Russian Far East (Tchabanenko, 2002), counting 943 species. In subsequent years more than 30 publications were added (e.g. Joneson, 2004; Pchelkin, 2008; Velikanov \& Skirina, 2012; Ezhkin \& Galanina, 2014; Zhurbenko, 2014; Skirina, 2015, 2016) about lichens in this area. However, lichen biota of the Amur Region has not been comprehensively studied. Most researchers have investigated lichens within three nature reserves - Norsky, Khingansky and Zeysky. The lists of lichens of Norsky and Khingansky reserves counted 308 (Pchelkin \& Pchelkina, 2013) and 63 (Mikulin, 1998) species, respectively. Some results of lichenological investigations in the Zeysky Reserve were published in the last decades of 20th century (Petelin et al., 1981; Tolpysheva et al., 1981; Stetsura, 1986; Makryi \& Stetsura, 1987; Tolpysheva \& Zhiryakova, 1988, 1990; Guseva et al., 1993). The list of lichens compiled on the base of these publications counted 51 species only (Urbanavichus \& Urbanavichene, 2004).
Current paper aims to improve our knowledge about lichen diversity of the Zeysky Nature Reserve - one of the least investigated reserves in the Russian Far East. Of 40 species presented here, 36 are recorded for the first time for the Zeysky Nature Reserve, Amur Region, Asian part of Russia, Russia or Asia. Parmelia asiatica is reported for the first time for the southern Russian Far East, Cladonia norvegica - for the Asian part of Russia, Tuckermannopsis gilvafor Russia, Melanohalea laciniatula - for Asia. Four species are included in the Red Data Book of Russian Federation (Red..., 2008). Thus, the list of species nowadays known in the Zeysky Nature Reserve has increased to 87 species. Considering the wide area of the reserve and high diversity of ecosystems and phorophytes in it, we can assume that this is only a small part of the real diversity of lichens. Obviously further investigation is urgently needed.

\section{STUDY AREA}

Zeysky Nature Reserve was established in 1963 and is located on the eastern part of the Tukuringra Ridge in the Amur Region of the Russian Far East. The reserve occupies $994 \mathrm{~km}^{2}$. The $40 \%$ of this territory is under $700 \mathrm{~m}$ a.s.1., $35 \%$ - from 700 to $1000 \mathrm{~m}, 18 \%$ - from 1000 to 
$1300 \mathrm{~m}$, and $7 \%$ - above $1300 \mathrm{~m}$. The climate of the study area is continental, with monsoon features, it is characterized by long, severe winters (not very snowy) and warm summers. The average monthly temperatures range from $-30.6^{\circ} \mathrm{C}$ in January to $+18.2^{\circ} \mathrm{C}$ in July. The total annual precipitations are between $500 \mathrm{~mm}$ in foothills to more than $1500 \mathrm{~mm}$ in upper belts. More than $80 \%$ of them fall in summer months (Vasiljev et al., 1985).

There are three defined belts in vegetation. Above $1000 \mathrm{~m}$ a.s.1. elfinwoods [Pinus pumila (Pall.) Regel] and tundra with dwarf shrubs dominance grow. Taiga belt occupies altitudes between 300 to $1000-1200 \mathrm{~m}$ a.s.1. and consists of larch [Larix gmelinii (Rupr.) Rupr.] and spruce forests [Picea ajanensis (Lindl. \& Gord.) Fisch. ex Carr.]. Hemiboreal larch and oak-black birch (Quercus mongolica Fisch. ex Ledeb., Betula davurica Pall.) forests with manchurian floristic complex occupy the warmest south-facing slopes (250-400 $\mathrm{m}$ a.s.1.) and are situated on the northern limit of their distribution.

\section{MATERIALS AND METHODS}

The materials for the present research were collected by Sergey V. Dudov in August and September 2016 during geobotanical investigations in the Zeysky Reserve and its vicinity (Fig. 1). Dissecting microscope, light microscope and UV light cabinet were used for the identification of lichen specimens. Voucher specimens are deposited mainly in the herbarium of Komarov Botanical Institute RAS (LE); some specimens are stored in the herbarium of Zeysky Nature Reserve (HerbZR). The species included in the Red Data Book of Russian Federation (Red..., 2008) are marked with *, lichenicolous fungus with \#. Zeysky Reserve and Amur Region are abbreviated as $\mathrm{ZR}$ and $\mathrm{AR}$, respectively. The nomenclature of the cited taxa mainly follows Nordin et al. (2011) and Esslinger (2016). The species in the list are accompanied by the data about localities, substrates, herbaria and references.

\section{List of localities}

Zeysky Reserve, Tukuringa Ridge: $1-54^{\circ} 07^{\prime} 54.1^{\prime \prime} \mathrm{N}$, $126^{\circ} 43^{\prime} 44.4^{\prime \prime} \mathrm{E}, 583 \mathrm{~m}$ a.s.1., the valley of the right tributary of the Kamenushka River, near its mouth, spruce forest, 16.08.2016; $2-54^{\circ} 07^{\prime} 51.2 " \mathrm{~N}, 126^{\circ} 44^{\prime} 13.2$ " $\mathrm{E}$, $599 \mathrm{~m}$ a.s.1., fluvial terrace of the Kamenushka River, sparse larch forest, 16.08.2016; 3 - 54 $09^{\prime} 22.0^{\prime \prime} \mathrm{N}$, $126^{\circ} 47^{\prime} 56.4^{\prime \prime} \mathrm{E}, 1299 \mathrm{~m}$ a.s.1., the main watershed of the ridge in the upper reaches of the Banny spring and Stepanak rivers, tundra with mosses and dwarf shrubs, 17.08.2016; $4-54^{\circ} 09^{\prime} 46.8^{\prime \prime} \mathrm{N}, 126^{\circ} 46^{\prime} 44.4 " \mathrm{E}$, $1268 \mathrm{~m}$ a.s.1., the main watershed of the ridge in the upper reaches of the Kamenushka River, tundra with dwarf shrubs, mosses and lichens, 18.08.2016; 5 $53^{\circ} 52^{\prime} 26.8$ "N, $127^{\circ} 06^{\prime} 50.4 " \mathrm{E}, 503 \mathrm{~m}$ a.s.1., vicinity of cordon " $20^{\text {th }} \mathrm{km}$ ", larch-birch forest, 22.08.2016; $6-53^{\circ} 52$ '22.1”N, $127^{\circ} 06^{\prime} 54.0 ” E$, $498 \mathrm{~m}$ a.s.1., vicinity of cordon "Nizhny Chimchan", peat bog with larches, 23.08.2016; 7 - 54²14'59.3”N, 12653'38.4”E, 334 $\mathrm{m}$ a.s.1., right side of the Gilui River valley above the Razvedochny spring, larch forest with young spruces, 25.08.2016; 8 - 54¹5'03.6”N, 12654'07.2”E, 422 $\mathrm{m}$ a.s.1., left side of the Razvedochny spring valley, larch forest with birch, 26.08.2016; 9-54 ${ }^{\circ} 15^{\prime} 01.8^{\prime \prime} \mathrm{N}$, $126^{\circ} 54^{\prime 7} .2$ "E, $403 \mathrm{~m}$ a.s.1., left side of the Razvedochny

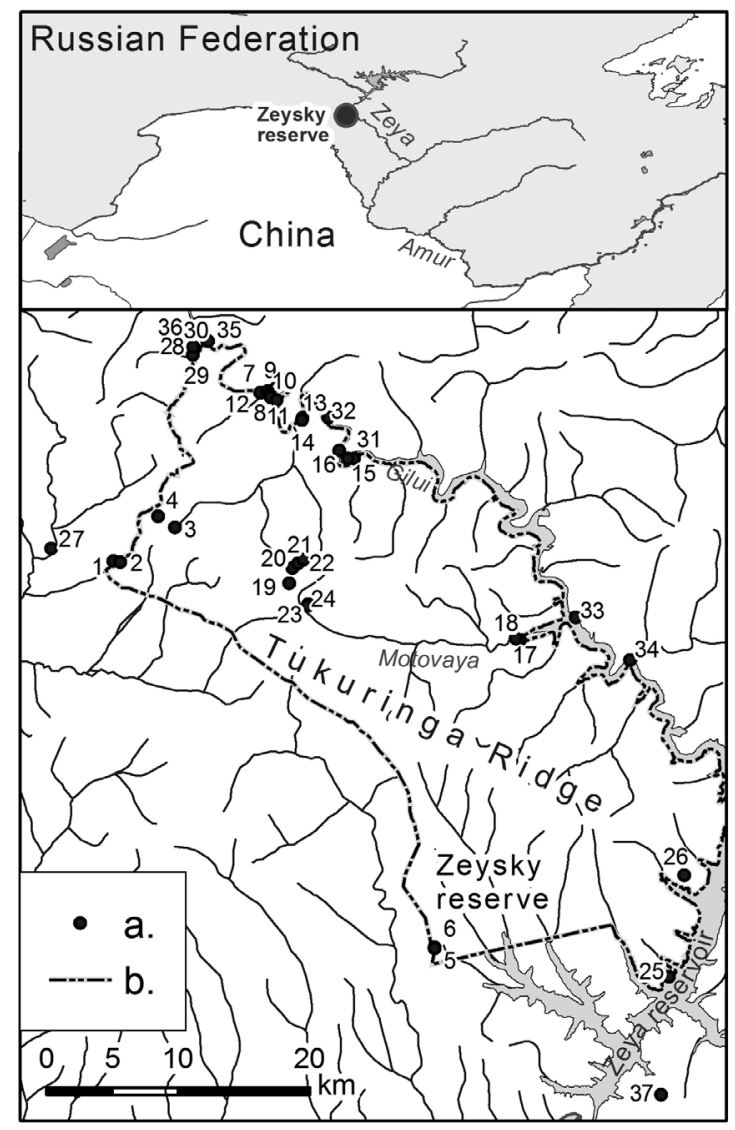

Fig. 1. A. Location of the study area; B. Collection sites within Zeysky Nature Reserve and in its vicinities: $a$ - collection sites, $b$ - border of the Zeysky Nature Reserve. 
spring valley, aspen-birch-larch forest on rock debris, 26.08.2016; $10-54^{\circ} 14^{\prime} 54.6^{\prime \prime} \mathrm{N}, 126^{\circ} 54^{\prime} 14.4$ "E, $373 \mathrm{~m}$ a.s.1., Razvedochny spring valley, sparse larch forest, 26.08.2016; $11-54^{\circ} 14^{\prime} 47.8$ "N, 12654'21.6” E, 448 $\mathrm{m}$ a.s.1., left side of the Strelka spring valley, $1.5 \mathrm{~km}$ above the mouth, birch-larch forest, 26.08.2016; 12 $54^{\circ} 14^{\prime} 42.4^{\prime \prime} \mathrm{N}, 126^{\circ} 54^{\prime} 46.8^{\prime} \mathrm{E}, 353 \mathrm{~m}$ a.s.1., left side of the Strelka spring valley, near the mouth, birch-larch forest, 26.08.2016; $13-54^{\circ} 13^{\prime} 59.5^{\prime \prime} \mathrm{N}, 126^{\circ} 56^{\prime} 38.4^{\prime \prime} \mathrm{E}$, $387 \mathrm{~m}$ a.s.1., right side of the Gilui River valley, below the mouth of the Stepanak River, larch-aspen-birch forest, 27.08.2016; $14-54^{\circ} 13^{\prime} 54.8^{\prime \prime} \mathrm{N}, 126^{\circ} 56^{\prime} 34.8^{\prime \prime} \mathrm{E}$, $350 \mathrm{~m}$ a.s.1., right side of the Gilui River valley, below the mouth of the Stepanak River, screes of big rock fragments, 27.08.2016; 15 - 54 ${ }^{\circ} 12$ '24.1"N, $127^{\circ} 00^{\prime} 18.0^{\prime \prime E}, 316 \mathrm{~m}$ a.s.1., the right bank of the Gilui Bay of the Zeya Reservoir near the cordon "Izubriny", sparse larch woodland, 30.08.2016; $16-54^{\circ} 12^{\prime} 42.8^{\prime \prime} \mathrm{N}$, $126^{\circ} 59^{\prime} 16.5^{\prime} \mathrm{E}, 320 \mathrm{~m}$ a.s.1., the right bank of the Gilui Bay of the Zeya Reservoir, $2 \mathrm{~km}$ above the cordon "Izubriny", meadow with dry birches, 30.08.2016; 17 $-54^{\circ} 05^{\prime} 08.9^{\prime \prime} \mathrm{N}, 127^{\circ} 12^{\prime} 14.4^{\prime \prime} \mathrm{E}, 333 \mathrm{~m}$ a.s.1., the right side of the Motovaya River valley, sparse larch woodland, 31.08.2016; $18-54^{\circ} 05^{\prime} 12.5^{\prime} \mathrm{N}, 127^{\circ} 11^{\prime} 56.4^{\prime \prime} \mathrm{E}$, $333 \mathrm{~m}$ a.s.1., Motovaya River valley, spruce-poplar forest, 31.08.2016; $19-54^{\circ} 07^{\prime} 50.2$ "N, 126 ${ }^{\circ} 56^{\prime} 13.2$ " E, $1282 \mathrm{~m}$ a.s.1., the main watershed of the ridge in the upper reaches of the Motovaya River, birch elfinwood, 05.09.2016; 20 - 54º8'02.8”N, 12656’38.4”E, 1376 $\mathrm{m}$ a.s.1., the main watershed of the ridge in the upper reaches of the Motovaya River, Calamagrostis purpurea (Trin.) Trin. meadow dominance, 05.09.2016; $21-54^{\circ} 08^{\prime} 11.4^{\prime \prime} \mathrm{N}, 126^{\circ} 57^{\prime} 00.0^{\prime} \mathrm{E}, 1400 \mathrm{~m}$ a.s.1., the main watershed of the ridge in the upper reaches of the Motovaya River and the Burlivy spring, tundra with mosses and lichens, 05.09.2016; $22-54^{\circ} 07^{\prime} 12.7^{\prime \prime} \mathrm{N}$, $126^{\circ} 56^{\prime} 02.4^{\prime \prime} \mathrm{E}, 1265 \mathrm{~m}$ a.s.1., the main watershed of the ridge in the upper reaches of the Bol'shaya Erakinga River, spruce forest, 06.09.2016; $23-54^{\circ} 06^{\prime 2} 2.0^{\prime \prime} \mathrm{N}$, $126^{\circ} 57^{\prime} 25.2$ "E, $860 \mathrm{~m}$ a.s.1., left side of the Motovaya River valley in the upper stream, aspen-birch-larch forest, 06.09.2016; $24-54^{\circ} 06^{\prime} 18.7^{\prime \prime} \mathrm{N}, 126^{\circ} 57^{\prime} 21.6^{\prime \prime} \mathrm{E}$, $821 \mathrm{~m}$ a.s.1., left side of the Motovaya River valley in the upper stream, aspen-larch forest, 06.09.2016; $25-53^{\circ} 51^{\prime} 28.4^{\prime \prime} \mathrm{N}, 127^{\circ} 23^{\prime} 09.6$ "E, $378 \mathrm{~m}$ a.s.1., cape in the Zeya Reservoir between the Razvedochny and Sukhoy gulfs, birch-larch forest, 09.09.2016; 26 535'08.4"N, $127^{\circ} 23^{\prime} 49.2^{\prime} \mathrm{E}, 334 \mathrm{~m}$ a.s.1., left side of the Beloborodovsky Bay, black birch-larch forest, 01.09. 2016. Vicinity of Zeysky Reserve, Tukuringa Ridge: 27 - 54 $08^{\prime} 19.3$ ” $\mathrm{N}, 126^{\circ} 39^{\prime} 21.6$ " $\mathrm{E}, 491$ $\mathrm{m}$ a.s.1., right side of the Obka River valley, $1.5 \mathrm{~km}$ above its mouth, birch-aspen forest, 15.08.2016; 28 $54^{\circ} 16^{\prime} 28.0^{\prime \prime} \mathrm{N}, 126^{\circ} 48^{\prime} 50.0^{\prime \prime} \mathrm{E}, 398 \mathrm{~m}$ a.s.1., the valley of the left tributary of the Nizhny Chimchan River, birch forest with larches, 23.08.2016; $29-54^{\circ} 16^{\prime} 46.2^{\prime \prime} \mathrm{N}$, $126^{\circ} 48^{\prime} 50.4$ "E, $575 \mathrm{~m}$ a.s.1., vicinity of cordon "Nizhny Chimchan", birch forest with young spruces, 23.08.2016; 30 - 54¹7’03.5”N, 12649'48.0”E, 406 $\mathrm{m}$ a.s.1., left side of the Gilui River valley opposite the mouth of the Nizhny Chimchan River, birch-larch forest, 24.08.2016; $31-54^{\circ} 12^{\prime} 23.4^{\prime \prime N}, 126^{\circ} 59^{\prime} 52.8^{\prime \prime} \mathrm{E}$, $315 \mathrm{~m}$ a.s.1., bank of the Gilui Bay of the Zeya Reservoir opposite the mouth of the Izubrynaya River, meadow with horsetail and reed, 28.08.2016; $32-54^{\circ} 14^{\prime} 02.8^{\prime \prime N}, 126^{\circ} 58^{\prime} 26.4^{\prime \prime E}, 319 \mathrm{~m}$ a.s.1., left bank of the Gilui Bay of the Zeya Reservoir opposite the mouth of the Zolotoy spring, sparse larch forest, 29.08.2016; 33 - 54 ${ }^{\circ} 06^{\prime} 07.9$ ”N, 12716’04.8”E, 373 $\mathrm{m}$ a.s.1., left bank of the Gilui Bay opposite the mouth of the Motovaya River, sparse birch-larch forest with aspen, 31.08.2016; $34-54^{\circ} 04^{\prime} 25.7^{\prime \prime} \mathrm{N}, 127^{\circ} 19^{\prime} 55.2$ 'E, $336 \mathrm{~m}$ a.s.1., left bank of the Gilui Bay between the Lugerkan and Tabuneika rivers, larch-aspen forest, 01.09.2016; 35 - 54²17'02.4”N, 12649'51.6”E, 414 $\mathrm{m}$ a.s.1., left side of the Gilui River valley opposite the mouth of the Nizhny Chimchan River, larch-spruce forest, 24.08.2016; $36-54^{\circ} 16^{\prime} 54.5^{\prime \prime} \mathrm{N}, 126^{\circ} 49^{\prime} 12.4$ " $\mathrm{E}$, $550 \mathrm{~m}$ a.s.1., vicinity of cordon "Nizhny Chimchan", larch forest with birch, 23.08.2016. Vicinity of Zeysky Reserve: 37 - 5346’39.7”N, 127²2'44.4”E, 702 $\mathrm{m}$ a.s.1., the Soktahan Range, $5 \mathrm{~km}$ to the $\mathrm{E}$ of Zeya town, birch-larch forest, 21.08.2016.

\section{THE SPECIES}

\#ABrothallus PARMELIARUm (Sommerf.) Arnold 6,10 , thalli of Melanohalea spp. (HerbZR). - New to AR. Distribution in the Russian Far East: Jewish Autonomous Region, Chukotka Autonomous Okrug, Kamchatka Territory (Zhurbenko, 2014).

BRYORIA AMERICANA (Motyka) Holien - 2, 10, 36, bark of birch and larch (HerbZR). - New to ZR. Distribution in the southern Russian Far East: Amur Region (Pchelkin, 2008; Pchelkin \& Pchelkina, 2013), Primorye Territory (Skirina, 2016).

Bryoria Nitidula (Th. Fr.) Brodo \& D. Hawksw. - 3, soil (HerbZR). - New to AR. Distribution in the Russian Far East: Chukotka Autonomous Okrug (Makarova \& Katenin, 2009), Kamchatka Territory (Himelbrant et al., 2014), Khabarovsk Territory, Magadan Region, Sakhalin Island (Kotlov, 1995; Tchabanenko, 2002).

BRYORIA SIMPLICIOR (Vain.) Brodo \& D. Hawksw. $-15,31$, twigs of larch (LE). - New to AR. Distribution in the Russian Far East: Chukotka Autonomous Okrug (Andreev et al., 1996), Kamchatka Territory (Mikulin, 1990), Khabarovsk Territory, Magadan Region, Primorye Territory (Kotlov, 1995; Tchabanenko, 2002; Skirina, 2016).

CHRYSOTHRIX CHLORINA (Ach.) J.R. Laundon - 14, vertical surface of large stones (HerbZR). 
- New to ZR. Distribution in the southern Russian Far East: Amur Region (Pchelkin \& Pchelkina, 2013), Jewish Autonomous Region (Skirina, 2015), Khabarovsk Territory, Primorye Territory (Tchabanenko, 2002; Skirina, 2016).

Cladonia alini Trass - 21, soil (LE). - New to AR. Distribution in the Russian Far East: Chukotka Autonomous Okrug (Andreev et al., 1996), Magadan Region (Kotlov, 1995), Khabarovsk Territory, Primorye Territory (Tchabanenko, 2002; Skirina, 2016).

Cladonia CRispata (Ach.) Flot. var. CRISPATA - 20, soil (HerbZR). - New to ZR. Distribution in the southern Russian Far East: Amur Region (Pchelkin \& Pchelkina, 2013), Jewish Autonomous Region (Skirina, 2015), Primorye Territory, Khabarovsk Territory, Sakhalin and Paramushir islands (Tchabanenko, 2002; Skirina, 2016).

Cladonia Cyanipes (Sommerf.) Nyl. - 12, fallen wood (HerbZR). - New to AR. Distribution in the Russian Far East: Chukotka Autonomous Okrug (Makarova \& Katenin, 2009), Jewish Autonomous Region (Skirina, 2015), Kamchatka Territory (Mikulin, 1988), Magadan Region (Kotlov, 1995), Primorye Territory (Tchabanenko, 2002).

Cladonia MACROPHYllodes Nyl. - 4, soil (HerbZR). - New to AR. Distribution in the Russian Far East: Chukotka Autonomous Okrug (Andreev et al., 1996), Kamchatka Territory (Mikulin, 1988), Magadan Region (Kotlov, 1995), Primorye Territory (Tchabanenko, 2002).

Cladonia norvegica Tønsberg \& Holien - 13, 22, 37 , base of trunks of larch and spruces (LE). - New to the Asian part of Russia. In Russia it is known in the Leningrad, Kaluga, Murmansk, Tver, Vologda regions and Republic of Komi (Urbanavichus \& Urbanavichene, 2004; Fadeeva et al., 2007; Kuznetsova et al., 2007; Muchnik et al., 2009; Notov et al., 2011; Red..., 2015). World distribution: Europe, North and South America (Ahti et al., 2013) and Asia (Japan, closest to our locality) (Stenroos \& Ahti 1994). C. norvegica is easily distinguished due to bright red spots on thallus, caused by mite infection. The closest taxon is C. macilenta Hoffm., which has the same secondary metabolites but differs in red colour of apothecia and pycnidia (Ahti et al., 2013).
Cladonia sulphurina (Michx.) Fr. - 26, soil (HerbZR). - New to AR. Distribution in the Russian Far East: Chukotka Autonomous Okrug (Makarova \& Katenin, 2009), Jewish Autonomous Region (Skirina, 2015), Kamchatka Territory (Mikulin, 1987), Khabarovsk Territory (Velikanov \& Skirina, 2012), Magadan Region (Kotlov, 1995), Sakhalin and Paramushir islands (Tchabanenko, 2002).

*Coccocarpia ERYTHROXYLi (Spreng.) Swinscow \& Krog - 9, stones (LE). - Distribution in the southern Russian Far East: Amur Region (Pchelkin \& Pchelkina, 2013), Jewish Autonomous Region (Skirina, 2015), Khabarovsk Territory (Skirina, 2013), Primorye Territory (Tchabanenko, 2002; Skirina, 2016), Sakhalin Island (Skirina et al., 2016).

Collema subnigrescens Degel. - 13, 18, bark of aspen and twigs of spruce (LE). - New to ZR. Distribution in the southern Russian Far East: Amur Region (Pchelkin \& Pchelkina, 2013), Jewish Autonomous Region (Skirina, 2015), Khabarovsk Territory, Primorye Territory, Sakhalin and Kunashir islands (Tchabanenko, 2002; Skirina, 2016).

IMSHAUGIA ALEURITES (Ach.) S.L.F. Mey. - 15, twigs of larch (LE). - New to AR. Distribution in the Russian Far East: Chukotka Autonomous Okrug (Andreev et al., 1996), Kamchatka Territory (Mikulin, 1990), Khabarovsk Territory, Magadan Region, Primorye Territory, Sakhalin Island (Kotlov, 1995; Tchabanenko, 2002; Skirina, 2016).

LeCANORA AlBellula (Nyl.) Th. Fr. - 10, bark of larch (HerbZR). - New to AR. Distribution in the Russian Far East: Kamchatka Territory (Neshataeva et al., 2007), Primorye Territory (Skirina, 2016).

LePtogium aZuReum (Sw.) Mont. - 33, base of aspen trunk, mossy stones and lignum (LE). - New to AR. Distribution in the Russian Far East: Primorye Territory (Tchabanenko, 2002).

*LEPTOGIUM HiLdENBRANDil (Garov.) Nyl. - 13, 24, 27-30, 34, bark of aspen (LE). - Distribution in the southern Russian Far East: Amur Region, Jewish Autonomous Region, Khabarovsk Territory, Primorye Territory, Sakhalin Island (Tchabanenko, 2002; Skirina, 2015, 2016).

LEPTOGIUM PSEUdOPAPILLOSUM P.M. Jørg. - 1, 8, 28, bark of aspen and willow (LE). - New to AR. In Russia it is known only in the 
Jewish Autonomous Region (Makryi, 2014; Skirina, 2015).

*Lobaria PUlmonaria (L.) Hoffm. - 35, rock (HerbZR). - Distribution in the southern Russian Far East: Amur Region (Pchelkin \& Pchelkina, 2013), Primorye Territory, Khabarovsk Territory, Sakhalin Island (Tchabanenko, 2002; Skirina, 2016).

Melanohalea laciniatula (Flagey ex H. Olivier) O. Blanco - 29, bark of birch (LE). - New to Asia. In Russia it is known only in Northern Caucasus (Slonov, 2002). Outside Russia occurs in Europe and northern Africa (Westberg \& Thell, 2011).

Myelochroa METAREVOluTA (Asahina) Elix \& Hale $-5,18,24,25$, bark of aspen, birch and poplar (LE). - New to ZR. Distribution in the southern Russian Far East: Amur Region, Primorye Territory (Tchabanenko, 2002; Skirina, 2016), Sakhalin Island (Ezhkin \& Galanina, 2014).

*NEPHROMOPSIS LAURERI (Kremp.) Kurok. - 19, 22, 23, bark of spruce and birch (LE). - Distribution in the southern Russian Far East: Amur Region, Jewish Autonomous Region, Khabarovsk Territory, Primorye Territory, Sakhalin Island (Tchabanenko, 2002; Skirina, 2015, 2016).

OXNERIA ULOPHYLLODES (Räsänen) S.Y. Kondr. \& Kärnefelt - 18, bark of poplar (HerbZR). - New to ZR. Distribution in the southern Russian Far East: Amur Region (Pchelkin \& Pchelkina, 2013), Jewish Autonomous Region (Skirina, 2015), Primorye Territory (Tchabanenko, 2002).

Parmelia Asiatica A. Crespo \& Divakar - 36, bark and twigs of larch (LE) (Fig. 2). - New to the southern Russian Far East. P. asiatica was described from China (Lumbsch et al., 2011) and soon after was recorded in the Kamchatka Peninsula and Irkutsk Region (Lishtva et al., 2013). In 2015, the third Russian locality was recorded from Magadan Region (Zheludeva, 2015). P. asiatica differs from the widespread and chemically close $P$. sulcata Taylor by the narrow sublinear lobes with sparse pseudocyphellae and spherical or hemispherical terminal and linear marginal soralia (Lishtva et al., 2013).

Peltigera Didactyla (With.) J. R. Laundon - 16, 30, soil (HerbZR). - New to ZR. Distribution in the southern Russian Far East: Amur Region (Pchelkin \& Pchelkina, 2013), Jew- ish Autonomous Region (Skirina, 2015), Khabarovsk Territory, Primorye Territory, Sakhalin Island (Tchabanenko, 2002; Skirina, 2016).

Peltigera Elisabethae Gyeln. - 4, 17, soil (HerbZR). - New to ZR. Distribution in the southern Russian Far East: Amur Region (Pchelkin \& Pchelkina, 2013), Jewish Autonomous Region (Skirina, 2015), Primorye Territory, Khabarovsk Territory, Sakhalin Island (Tchabanenko, 2002; Skirina, 2016).

Peltigera NECKeri Hepp ex Müll. Arg. - 32, soil (LE). - New to AR. Distribution in the Russian Far East: Jewish Autonomous Region (Skirina, 2015), Kamchatka Territory (Mikulin, 1987), Khabarovsk Territory, Primorye Territory, Sakhalin Island (Tchabanenko, 2002; Skirina, 2016).

Peltigera NEOPOLYDACTYla (Gyeln.) Gyeln. - 22, soil (HerbZR). - New to AR. Distribution in the Russian Far East: Kamchatka Territory (Himelbrant et al., 2014), Primorye Territory, Sakhalin Island (Tchabanenko, 2002).

Peltigera PRAETEXTATA (Flörke ex Sommerf.) Zopf - 13, bark of aspen (HerbZR). - New to ZR. Distribution in the southern Russian Far East: Amur Region (Pchelkin \& Pchelkina, 2013), Jewish Autonomous Region (Skirina, 2015), Khabarovsk Territory, Primorye Territory, Sakhalin and Shikotan islands (Tchabanenko, 2002; Skirina, 2016).

PHAEOPHYSCIA HIRTELLA Essl. - 13, bark of aspen (LE). - New to AR. Distribution in the Rus-

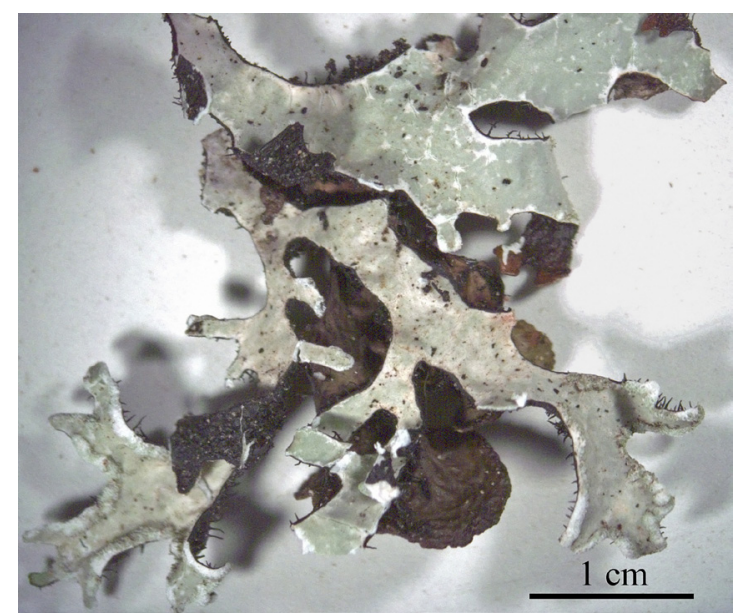

Fig. 2. Lobes of Parmelia asiatica with soralia. 
sian Far East: Jewish Autonomous Region (Skirina, 2015), Khabarovsk Territory (Tchabanenko, 2002), Primorye Territory (Skirin \& Skirina, 2014).

Phaeophyscia HiRTUOSA (Kremp.) Essl. - 13, 33, bark of aspen (LE). - New to ZR. Distribution in the southern Russian Far East: Amur Region (Pchelkin, 2008; Pchelkin \& Pchelkina, 2013), Jewish Autonomous Region (Skirina, 2015), Primorye Territory, Khabarovsk Territory, Sakhalin and Kunashir islands (Tchabanenko, 2002; Skirina, 2016).

PhaEOPHYSCIA RUBRopulchra (Degelius) Essl. - 5, bark of birch (LE). - New to ZR. Distribution in the southern Russian Far East: Amur Region (Pchelkin, 2008; Pchelkin \& Pchelkina, 2013), Jewish Autonomous Region (Skirina, 2015), Primorye Territory, Khabarovsk Territory, Sakhalin and Kunashir islands (Tchabanenko, 2002; Skirina, 2016).

Physconia Grumosa Kashiw. \& Poelt $-1,11$, $18,28,30$, bark of aspen, poplar and willow (LE). - New to AR. Distribution in the Russian Far East: Jewish Autonomous Region (Skirina, 2015), Kamchatka Territory (Himelbrant et al., 2009), Primorye Territory (Tchabanenko, 2002; Skirina, 2016), Sakhalin Island (Ezhkin, Galanina, 2014).

Platismatia interrupta W. L. Culb. \& C. F. Culb. 22, bark of birch (LE). - New to AR. Distribution in the Russian Far East: Jewish Autonomous Region (Skirina, 2015), Khabarovsk Territory, Primorye Territory, Sakhalin and Kunashir islands (Tchabanenko, 2002; Skirina, 2016).

RAMALINA POLLINARIA (Westr.) Ach. - 30, rock (HerbZR). - New to AR. Distribution in the Russian Far East: Jewish Autonomous Region (Skirina, 2015), Khabarovsk Territory, Primorye Territory, Sakhalin Island (Tchabanenko, 2002; Skirina, 2016).

RiNodina DEGELIANA Coppins - 2, bark of larch (HerbZR). - New to AR. Distribution in the Russian Far East: Jewish Autonomous District (Skirina, 2015), Kamchatka Territory (Himelbrant \& Stepanchikova, 2011), Primorye Territory (Skirina, 2016), Sakhalin Island (Skirina et al., 2016).

RINODINA XANTHOPHAEA (Nyl.) Zahlbr. $-2,7$, bark of larch and spruce (HerbZR). - New to ZR. Distribution in the southern Russian Far East: Amur Region, Jewish Autonomous Region,
Khabarovsk Territory, Primorye Territory, Sakhalin Island (Pchelkin, 2008; Pchelkin \& Pchelkina, 2013; Urbanavichene \& Skirina, 2011; Skirina, 2015, 2016), Kunashir Island (Tchabanenko, 2002).

Scoliciosporum CHLOROCOCCUM (Graewe ex Stenh.) Vězda - 19, 37, bark of birch (HerbZR). - New to ZR. Distribution in the Southern Russian Far East: Amur Region (Pchelkin \& Pchelkina, 2013), Jewish Autonomous Region (Skirina, 2015), Primorye Territory (Skirina et al., 2009; Skirina, 2016).

TRAPELIOPSIS GRANUlOSA (Hoffm.) Lumbsc - 4, soil, plant debris (HerbZR). - New to ZR. Distribution in the southern Russian Far East: Amur Region (Pchelkin, 2008; Pchelkin \& Pchelkina, 2013), Khabarovsk Territory (Tchabanenko, 2002).

TucKermanNopsis GILVA (Asahina) M. J. Lai - 22, bark of birch [Betula lanata (Regel) V. N. Vassil.] (LE) (Fig. 3). - New to Russia. World Distribution: Japan (Kärnefelt \& Thell, 2001) and North Korea (Jeon et al., 2009). There are two more sorediate species known in the genus - T. chlorophylla (Willd.) Hale and T. ulophylloides (Asahina) M.J. Lai. The former taxon is widespread in the Northern Hemisphere while the latter is recorded from Japan and China (Lai, 1980, 2009) only. T. gilva is distinguished from T. ulophylloides by lacking cilia, and from $T$. chlorophylla by positive (rose) reaction with $\mathrm{KC}$ (alectoronic acid) (Kärnefelt \& Thell, 2001).

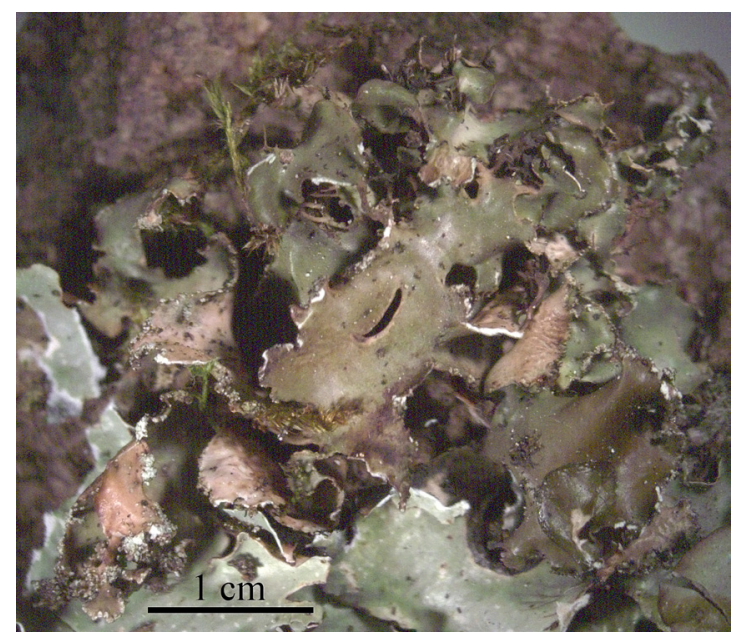

Fig. 3. Thallus of Tuckermannopsis gilva. 


\section{AKNOWLEDGEMENTS}

The present investigation was carried out within the framework of the research project (no. 01201255601) of the Komarov Botanical Institute of the Russian Academy of Sciences. The study of Sergey V. Dudov was financially supported by Russian Foundation for Basic Research (grant 16-35-00505).

\section{REFERENCES}

Ahti, T. Stenroos, S. \& Moberg, R. (eds). 2013. Cladoniaceae. Nordic Lichen Flora 5. 117 pp.

Andreev, M. P., Kotlov, Yu. V. \& Makarova, I. I. 1996. Checklist of Lichens and Lichenicolous Fungi of the Russian Arctic. Bryologist 99(2): 137-169. https:/ / doi.org/ 10.2307/3244545

Esslinger, T. L. 2016. A cumulative checklist for the lichen-forming, lichenicolous and allied fungi of the continental United States and Canada. Ver. 21. Opuscula Philolichenum 15: 135-390.

Ezhkin, A. K. \& Galanina, I. A. 2014. Additions to the lichen biota of the Sakhalin Island. Novitates Systematicae Plantarum Non Vascularum 48: 233-248. (In Russian, English summary).

Fadeeva, M. A., Golubkova, N. S., Vitikainen, O. \& Ahti, T. 2007. Conspectus of lichens and lichenicolous fungi of the Republic of Karelia. Petrozavodsk, 194 pp. (In Russian, English summary).

Guseva, S. G., Stepanenko, L. S., Knyazheva, L. A., Skirina, I. F. \& Dmitrenok, P. S. 1993. Genera Cetrelia and Platismatia (Lichenes) in the flora of the southern Russian Far East. Botanical Journal 78(7): 38-45. (In Russian).

Himelbrant, D. E. \& Stepanchikova, I. S. 2011. The lichen flora of Kamchatka fir grove (Kronotsky Reserve). Novitates Systematicae Plantarum Non Vascularum 45: 150-158. (In Russian).

Himelbrant, D. E., Stepanchikova, I. S. \& Kuznetsova, E. S. 2009. Lichens of some shrubs and dwarf shrubs of Kamchatka Peninsula. Novitates Systematicae Plantarum Non Vascularum 43: 150-171. (In Russian)

Himelbrant, D. E., Stepanchikova, I. S. \& Kuznetsova, E. S. 2014. Lichens. In: The vegetation cover of the volcanic plateau of Central Kamchatka. Moscow, pp. 121-164. (In Russian).

Jeon, H.-S., Koh, Y.-J., Lökös, L., Lee, Y.-M., Byun, B.-K. \& Hur, J.-S. 2009. Report on the lichen list of North Korea. The Korean Journal of Mycology 37: 1-10. https://doi.org/10.4489/ KJM.2009.37.1.001

Joneson, S., Kashiwadani, H., Tchabanenko, S. \& Gage, S. 2004. Ramalina of Kuril Islands. Bryologist 107(1): 98-106. https://doi.org/10.1639/00072745(2004)107[98:ROTKI]2.0.CO;2

Kärnefelt, I. \& Thell, A. 2001. Delimitation of the lichen genus Tuckermannopsis Gyeln. (Ascomycotina,
Parmeliaceae) based on morphology and DNA sequences. Bibliotheca Lichenologica 78: 193-209.

Kotlov, Yu. V. 1995. Materials to the lichen flora of Upper Kolyma Highland. Novitates Systematicae Plantarum Non Vascularum 30: 66-72. (In Russian).

Kozhemyako, O. N. (ed.) 2009. Red Data Book of Amur Region: rare and endangered species of animals, plants and fungi. Blagoveschensk. 446 pp. (In Russian).

Kuznetsova E., Ahti T. \& Himelbrant D. 2007. Lichens and allied fungi of the Eastern Leningrad Region. Norrlinia 16:1-62.

Lai, M. J. 1980. Studies on the cetrarioid lichens in Parmeliaceae of East Asia. Quarterly Journal of the Taiwan Museum 33(3-4): 215-229. https:// doi.org/10.5735/085.046.0501

Lai, M. J., Chen, X. L., Qian, Z. G., Xu, L. \& Ahti, T. 2009: Cetrarioid lichen genera and species in NE China. Annales Botanici Fennici 46: 365-380.

Lishtva, A. V., Himelbrant, D. E. \& Stepanchikova, I. S. Parmelia asiatica (Parmeliaceae): the first record for the lichen flora of Russia. Novitates Systematicae Plantarum Non Vascularum 47: 225-229.

Lumbsch, T. H., Ahti, T., Altermann, S., et al. 2011. One hundred new species of lichenized fungi: a signature of undiscovered global diversity. Phytotaxa 18: 1-127. https://doi.org/10.11646/ phytotaxa.18.1.1

Makarova, I. I. \& Katenin, A. E. 2009. Lichens of "Berengia" Nature Park (north-eastern Chukotka Peninsula). Novitates Systematicae Plantarum Non Vascularum 43: 172-189. (In Russian).

Makryi, T. V. 2014. A review of the sect. Mallotium of the genus Leptogium (Collemataceae) in Russia and L. pseudopapillosum and L. hirsutum new records for Russia. Novitates Systematicae Plantarum Non Vascularum 48: 264-290. (In Russian, English Summary).

Makryi, T. V. \& Stetsura, N. N. 1987. Additions to the lichen flora of the Zeysky Reserve (Amur Region). Bulletin of Moscow Society of Naturalists. Biological series 92(1): 130-132. (In Russian).

Mikulin, A. G. 1987. New lichen records for Kamchatka peninsula. Novitates Systematicae Plantarum Non Vascularum 24: 163-165. (In Russian).

Mikulin, A. G. 1988. Mountain lichens of Kronotsky State Reserve, Kamchatka. In: Vegetation of mountain ecosystems of the USSR. Vladivostok, pp. 149-158. (In Russian).

Mikulin, A. G. 1990. Handbook of lichens of Kamchatka Peninsula. Vladivostok, 128 pp. (In Russian).

Mikulin, A. G. 1998. Lichens. In: Flora and vegetation of Khingansky Reserve (Amur Region). Vladivostok, pp. 65-69. (In Russian, English summary).

Muchnik, E. E., Konoreva, L. A., Dobrysh, A. A., Makarova, I. I. \& Titov, A. N. 2009. Conspectus of lichens of Darvinsky State Natural Biosphere Reserve (Vologda and Yaroslavl regions, Russia). Herald of Tver State University. Biology and Ecology series 14: 174-194. (In Russian). 
Neshataeva, V. Yu., Vyatkina, M. P., Golovneva, L. B., Himelbrant, D. E., Chernyadjeva, I. V., Oskolsky, A. A. \& Stepanchikova, I. S. 2007. Poplar open woodlands on the volcanic deposits of Tolbachinsky Dol in the Kluchevskaya group of volcanoes (Central Kamchatka). Conservation of biodiversity of Kamchatka and coastal waters: Proceedings of VII international scientific conference. Petropavlovsk-Kamchatsky, pp. 92-119. (In Russian).

Nordin, A., Moberg, R., Tonsberg, T., Vitikainen, O., Dalsätt, A., Myrdal, M., Snitting, D. \& Ekman, S. 2011. Santesson's Checklist of Fennoscandian Lichen-forming and Lichenicolous Fungi. Ver. April 29, 2011 - http:130.238.83.220/santesson/ home.php (26 March 2017).

Notov, A. A., Himelbrant, D. E. \& Urbanavichus, G. P. 2011. The list of lichens and allied fungi of Tver Region. Tver, 124 pp. (In Russian).

Petelin, D. A., Tolpysheva, T. Yu. \& Tarasov, K. L. 1981. Lichen flora of Zeysky Reserve (Tukuringa Ridge, Amur Region). In: Bryological and lichenological investigations of high-mountains area and north of USSR. Apatity, pp. 104-105. (In Russian).

Pchelkin, A. V. 2008. Corticolous lichens of Norsky Reserve. In: Modern mycology in Russia. Vol. 2. Materials of the $2^{\text {nd }}$ congress of mycologists in Russia. Moscow, pp. 534-535. (In Russian).

Pchelkin, A. V. \& Pchelkina, T. A. 2013. Upgraded list of lichens of the Norsky Reserve. In: Collection of articles to the $15^{\text {th }}$ anniversary of Norsky Reserve. Blagoveshchensk-Fevral'sk, pp. 33-58. (In Russian).

Red Data Book of Kaluga Region. Vol. 1. Plants. 2015. Kaluga, 536 pp. (In Russian).

Red Data Book of Russian Federation (Plants and Fungi). 2008. Moscow, 855 pp. (In Russian).

Skirina, I. F. 2015. Lichen list of "Bastak" Natural Reserve (Russia). Biodiversity and Environment of Far East Reserves 4: 28-87. (In Russian, English summary).

Skirina, I. F. 2016. Lichens. In: Plants, fungi and lichens of the Sikhote-Alin Reserve. Vladivostok, pp. 458-525. (In Russian).

Skirina, I. F., Rodnikova, I. M. \& Skirin, F. I. 2009. Lichen species from Prikhankayskaya Valley (Primorie Territory). Novitates Systematicae Plantarum Non Vascularum 43: 213-228. (In Russian).

Skirina, I. F., Salokhin, A. V., Tsarenko, N. A. \& Skirin, F. V. 2016. New locations of protected lichens of Sakhalin island. Turczaninowia 19(2): 54-63. (In Russian, English summary). https://doi. org/10.14258/turczaninowia.19.2.6

Skirina, I. F. \& Skirin, F. V. 2014. Rare and poorly studied lichens of Primorskiy Krai (Russian Far East). Turczaninowia 17(2): 49-52. (In Russian, English summary). https://doi.org/10.14258/ turczaninowia. 17.2.7
Slonov, T. L. 2002. Lichen flora of Cabardino-Balkaria and its analyses. Nalchik, 136 pp. (In Russian).

Stenroos, S. \& Ahti, T. 1994. A synopsis of the Japanese taxa of Cladonia sect. Cocciferae. Journal of the Hattori Botanical Laboratory 75: 305-318.

Stetsura, N. N. 1986. Threatened fungi, lichens and mosses of the Zeysky Reserve. In: Abstracts of All-Union Meeting "Problems of gene pool protection and ecosystem management in the reserves of forest zone". 1. Moscow, pp. 202-204. (In Russian).

Tchabanenko, S. 2002. Conspectus of lichens of south of The Russian Far East. Vladivostok, 232 pp. (In Russian, English summary).

Thell, A. \& Moberg, R. (eds). 2011. Parmeliaceae. Nordic Lichen Flora 4. 184 pp.

Tolpysheva, T. Yu., Petelin, D. A. \& Tarasov, K. L. 1981. Flora and vegetation of Tukuringa Ridge. Moscow, pp. 50-64. (In Russian).

Tolpysheva, T. Yu. \& Zhiryakova, E. D. 1988. Lichens of Picea ajanensis (Lindl. \& Gord.) Fisch. ex Carr. and $P$. koraiensis Nakai. Novitates Systematicae Plantarum Non Vascularum 25: 137-147. (In Russian).

Tolpysheva, T. Yu. \& Zhiryakova, E. D. 1990. Zeysky State Reserve as a refuge of lichens. In: Reserves of the USSR - their present and future. Abstracts of All-Union Conference. P. 2. Novgorod, pp. 200-202. (In Russian).

Urbanavichene, I. N. \& Skirina, I. F. 2011. Rinodina xanthophaea (Physciaceae) in Russia. Novitates Systematicae Plantarum Non Vascularum 45: 237-241. (In Russian).

Urbanavichus, G. P. \& Urbanavichene, I. N. 2004. Lichens. In: The Present-Day State of Biological Diversity within Protected Areas in Russia. Iss. 3. Lichens and Bryophytes. Moscow, pp. 5-235. (In Russian).

Vasiljev, N. G., Matushkin, E. N. \& Kuptsov, Yu. V. 1985. Zeysky Reserve. In: Reserves of the USSR. Reserves of the Far East. Moscow, pp. 92-113. (In Russian).

Velikanov, A. V. \& Skirina, I. F. 2012. Lichens of Lanzhinskiye Mountains (Okhotia). Herold of North-Eastern Research Centre FEB RAS 2: 69-77. (In Russian)

Zheludeva, E. V. 2015. Lichen species from NorthEastern Priokhotye (Okhotsk Sea region) new for Magadan Region. Turczaninowia 18(4): 5-15. (In Russian). https://doi.org/10.14258/turczaninowia. 18.4.1

Zhurbenko, M. P. 2014. Lichenicolous fungi from Far East of Russia. Folia Cryptogamica Estonica 51: 113-119. https://doi.org/10.12697/ fce. 2014.51 .13 